DOI: 10.17707/AgricultForest.63.4.06

\author{
Farida BENZINA, Hakima OULEBSIR-MOHANDKACI, \\ Messaouda BELAID, Hamama IRNATENE, Sonia MAMMERI ${ }^{1}$
}

\title{
ISOLATION OF ENTOMOPATHOGENIC BACTERIA FROM LARVAE \\ OF A LEPIDOPTERAN SPECIE; GALLERIA MELLONELLA AND STUDY OF THEIR INSECTICIDAL EFFECT
}

\begin{abstract}
SUMMARY
Few years ago, considerable progress has been made to explain the disappearance of bee colonies, including correct identification of pests involved and the search for more effective and healthy alternatives to protect them. Indeed, our work is based on the isolation, characterization and identification of entomopathogenic bacterial strains of the genus Bacillus from larvae of wax moth Galleria mellonela reared in the laboratory, with a preliminary study of the use of these entomopathogenic bacteria on the larvae (L5) of G. mellonella under controlled conditions. In fact, 9 bacterial strains of the genus Bacillus have been isolated. They are spore forming bacteria, Gram, catalase and oxidase positive and present variable responses to the gelatinase test, lecitinase, caseinase, culture in anaerobiosis and growth at different temperatures $\left(45^{\circ} \mathrm{C}\right.$., $55^{\circ} \mathrm{C}$., $65^{\circ} \mathrm{C}$.). From our study, we also find that the strain S4, probably identified as Bacillus thuringiensis, has a better effect on the larvae of Galleria mellonella. It caused very remarkable symptoms and mortality rates that vary depending on the strain and bacterial concentration tested and the mode of application. Injection of strain S4 for individuals resulted mortality of $83.33 \%, 75 \%$ and $50 \%$, respectively, after treatment with high, medium and low concentration after only 3 days. The comparative examination of the hemolymph test results shows that the injection of the bacteria into the larvae resulted in a significant increase in hemolymph protein and carbohydrate content as compared to controls.
\end{abstract}

Keywords: Galleria mellonella, Bacillus, isolation, mortality, haemolymph.

\section{INTRODUCTION}

Honeybee pests are known to cause significant losses, and to transmit viral pathogens for which therapies remain nonexistent and continue to be challenging to eradicate (Plettner et al., 2017). The greater wax moth, Galleria mellonella

\footnotetext{
${ }^{1}$ Farida Benzina, Hakima Oulebsir-Mohandkaci (corresponding author: mohandkacihakima@yahoo.fr), Laboratory of Valorisation and Conservation of Biological Resources, Faculty of Sciences, University M'hamed Bougara of Boumerdes, ALGERIA; Messaouda Belaid, Hamama Irnatene, Sonia Mammeri, Department of Biology, Faculty of Sciences, University M'hamed Bougara of Boumerdes, ALGERIA.

Paper presented at the $8^{\text {th }}$ International Scientific Agricultural Symposium "AGROSYM 2017".

Notes: The authors declare that they have no conflicts of interest. Authorship Form signed online.
} 
Linnaeus, is a ubiquitous pest of the honeybee, Apis mellifera. The damage caused by G. mellonella larvae is severe, and is believed to be one of the contributing factors to the decline in honeybee populations. Previously, the pest was Considered a nuisance in honeybee colonies, it is currently widespread, especially in Africa, and the potential of transmitting honeybee viruses has raised legitimate concern.(Kwadha et al., 2017). The wax moth was first reported in honeybee colonies of Asian honeybee Apis cerana (Paddock, 1918), but later spread to northern Africa, and other parts of the world (Akratanakul , 1987). Shimanuki (1980) and Williams (1997) later described the pests as ubiquitously distributed everywhere beekeeping is practiced.

Use of chemical and fumigant insecticides to destroy this insect are harmful to bee populations ( Calderone, 2000). Certains pose health risks to the handler and lead to residues in hive products such as honey, rendering the product inconsumable (Ritter and Akratanakul 2006). More importantly, they are poisonous to honeybee colonies and non-target species (Ritter and Akratanakul, 2006; Charriere and Imdorf, 1999). Previous researchers have explored various biological agents and bio-products including Bacillus thuringiensis Berliner ( $\mathrm{H}$ serotype V) (Plettner al., 2017), but evidence for a successful and sustainable biological control agent of $G$. mellonela is still lacking. The objective of the present study is to screen different bacterial strains from the cadavers of the greater wax moth reared on laboratory and testing them against the larva of this insect, in order to explore the toxins of these bacteria.

\section{MATERIAL AND METHODS \\ Isolation and characterization of bacterial strains}

From the larva of the greater wax moth accidentally contaminated in the laboratory during the various manipulations, a few individuals were isolated immediately after their death. These were deposited on the surface of a nutrient agar and then incubated at $32^{\circ}$ C. 24 hours after incubation, bacterial colonies were obtained around the deposited cadavers. Successive transplants have resulted pure and well-defined colonies. Only colonies with the macroscopic characters of the genus Bacillus are taken into consideration.

Preliminary identification of the isolates took place according to the taxonomic characterization proposed by Guiraud (2003). For this, a macroscopic examination of the colonies constitutes a first step which guides the process of characterization of the bacteria. Microscopic examination consists of microscopic observation in the fresh state followed by simple staining with methylene blue, Gram staining and spore staining (Larpen, 1997, Singleton, 2005). For the biochemical characterization, we used the classical identification tests and the API system. Among the tests performed; Simmons citrate test, Voges Proskauer reaction (VP), methyl red reaction (RM), TSI study, growth at $45^{\circ} \mathrm{C}, 55^{\circ} \mathrm{C}$ et $65^{\circ} \mathrm{C}$ (Guiraud, 2003). Among the enzymes researched; catalase, oxidase, caseinase, lecithinase, nitrate reductase (NR) (Geraldine et al., 1981; Graden and Luisetti, 1981; Gerard et al., 2003). 


\section{Treatment of larvae of the greater wax moth}

Fifth-stage healthy larvae were isolated from the rearing, these were treated by introducing 3 different concentrations of the bacterial suspensions, using 2 modes of application, ingestion and injection. The control and treated larvae are fed with honey, pollen and wax and placed in an oven at $30^{\circ} \mathrm{C}$. In order to study the efficacy of the two bacterial strains selected on the larvae of the greater wax moth, 3 parameters were chosen; Calculation of the corrected mortality, calculation of LT50 (lethal time for $50 \%$ of individuals), study of haemolymphatic composition. To study this last parameter, the treatment of larvae was done by injection of a volume of $20 \mu \mathrm{l}$ of the bacterial suspension by individuals, controls received physiological saline. The haemolymph was taken $4 \mathrm{~h}, 6 \mathrm{~h}$ and $12 \mathrm{~h}$ after the treatment. Indeed, a volume of $10 \mu \mathrm{l}$ is taken at the abdominal end of the insect, $5 \mu \mathrm{l}$ are used for the determination of proteins and 5 $\mu \mathrm{l}$ for the determination of carbohydrates. The protein assay is carried out according to the method of Bradford (1976). The colorimetric method for the determination of carbohydrate by anthrone described by Bachelier and Gavinelli (1966) was used.

\section{Statistical analysis}

The significance of the main effects was determined by analysis of variance (ANOVA). The values $(\mathrm{p} \leq 0.05)$ are considered statistically significant. A correlation matrix is used to describe the degree of relationship between two variables. The software used is the Statistica.

\section{RESULTS AND DISCUSSION}

\section{Characterization of bacterial isolates}

The isolation of bacterial strains from G. mellonella larvae allowed the selection of 9 bacterial strains of the genus Bacillus.

Cultural and macroscopic tests: macroscopic examination on solid media (nutritive agar) showed well-isolated colonies.

Table 1. Cultural characteristics of isolates on solid medium

\begin{tabular}{|c|c|c|c|c|c|c|c|}
\hline Isolates & Shape & diameter & Color & Opacity & Elevation & Surface & Odor \\
\hline 1 & CIB & punctiform & white & opaque & flat & smooth & $\mathrm{Ab}$ \\
\hline 2 & CRB & punctiform & cream & opaque & flat & smooth & $\mathrm{Ab}$ \\
\hline 3 & CIB & $1.8 \mathrm{~mm}$ & cream & opaque & flat & smooth & $\mathrm{Ab}$ \\
\hline 4 & CIB & $1.6 \mathrm{~mm}$ & white & opaque & flat & smooth & $\mathrm{Ab}$ \\
\hline 5 & CRB & punctiform & white & opaque & flat & smooth & $\mathrm{Ab}$ \\
\hline 6 & CRB & $1.7 \mathrm{~mm}$ & white & opaque & flat & smooth & $\mathrm{Ab}$ \\
\hline 7 & CIB & $2 \mathrm{~mm}$ & white & opaque & Convex & Granular & $\mathrm{Ab}$ \\
\hline 8 & CIB & punctiforme & cream & opaque & Convex & Granular & $\mathrm{Ab}$ \\
\hline 9 & CRB & $1.3 \mathrm{~mm}$ & white & opaque & flat & smooth & $\mathrm{Ab}$ \\
\hline
\end{tabular}

*CIB : circular with irregular board, CRB : circular with regular board, Ab : absence 
Their appearance is very variable (table 1); they are opaque, cream or white colored colonies with an average diameter of 1.3 to $2 \mathrm{~mm}$. Some strains have punctiform colonies. The elevation differs from one isolate to the other between flat and convex, some colonies have a granular surface although the majority, their surface is smooth, the shape of the colonies obtained is circular with regular board or not.

The study of the cultural characteristics on liquid medium (nutrient broth) after incubation at $32{ }^{\circ} \mathrm{C}$ shows the presence of a cool at the bottom of the tube for most strains with the appearance of a homogeneous disorder and the presence veils and the ring surface (table 2).

Table 2. Cultivation characteristics on liquid medium

\begin{tabular}{|c|c|c|c|c|c|}
\hline Isolates & rings & sails & $\begin{array}{c}\text { homogeneous } \\
\text { disorder }\end{array}$ & $\begin{array}{c}\text { heterogeneous } \\
\text { disorder }\end{array}$ & cool \\
\hline S1 & + & + & + & - & + \\
\hline S2 & + & + & + & - & + \\
\hline S3 & + & + & + & - & + \\
\hline S4 & + & - & + & - & + \\
\hline S5 & + & + & + & - & + \\
\hline S6 & + & + & + & - & + \\
\hline S7 & + & + & + & - & + \\
\hline S8 & + & - & + & - & - \\
\hline S9 & + & - & + & - & + \\
\hline
\end{tabular}

$(+)$ : presence

(-) : absence

Microscopic characteristics of the isolates: microscopic observation of the cells after fresh staining, simple staining with methylene blue and Gram staining; has shown that all isolated strains have the shape of a rounded or square rod and are Gram-positive. Malachite green staining indicates that all isolated strains form spores. The spore has an oval shape in a central or terminal position (figure 1).

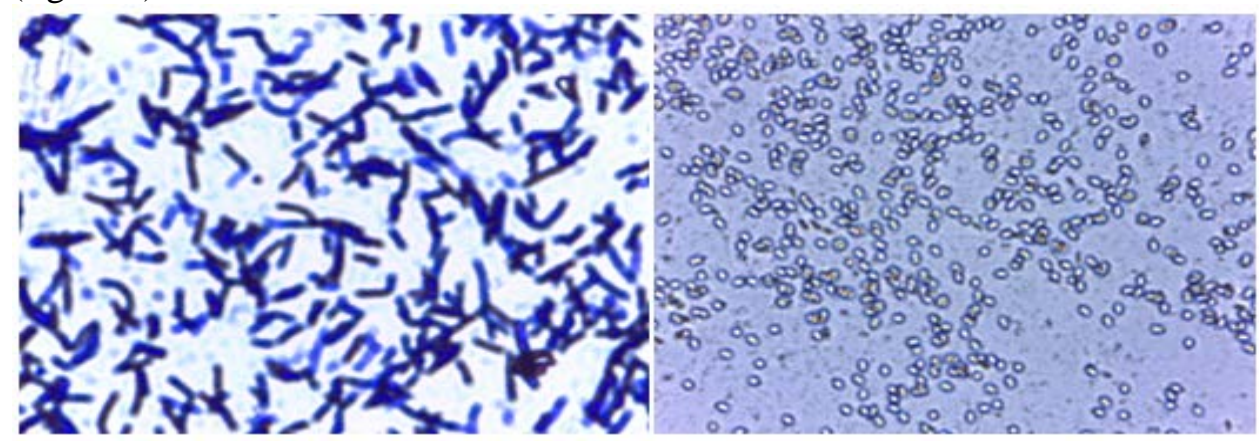

Figure 1: results of observation after Gram staining (right) and staining of spores (left)

Physiological and biochemical characterization: the results of the various biochemical tests carried out (table 3) indicate positive responses by all 
the strains for the oxidase, gelatinase, VP, TDA, ONPG, CIT, starch hydrolysis, catalase and caseinase tests, with negative responses for RHA, URA. The responses were variable for NO, MAN, ADH, lecithin, mobility, culture in anaerobiosis and growth at different temperatures $\left(45^{\circ} \mathrm{C}, 55^{\circ} \mathrm{C}, 65^{\circ} \mathrm{C}\right)$.

Table 3. Physiological and biochemical characterization of isolated strains

\begin{tabular}{|c|c|c|c|c|c|c|c|c|c|}
\hline APIsystem & S1 & S2 & S3 & S4 & S5 & S6 & S7 & S8 & S9 \\
\hline ARA & + & - & + & - & - & - & - & - & + \\
\hline AMY & + & - & + & - & - & - & - & + & + \\
\hline MEL & + & - & + & - & - & - & - & - & + \\
\hline SAC & - & - & - & - & - & - & - & - & + \\
\hline RHA & - & - & - & - & - & - & - & - & - \\
\hline SOR & + & + & - & - & + & + & - & - & + \\
\hline INO & + & - & - & - & - & - & + & + & - \\
\hline MAN & - & + & + & - & - & - & - & - & + \\
\hline GLU & - & - & - & - & - & + & - & - & + \\
\hline GEL & + & + & + & + & + & + & + & + & + \\
\hline VP & + & + & + & + & + & + & + & + & + \\
\hline IND & - & - & - & - & - & - & - & - & + \\
\hline TDA & + & + & + & + & + & + & + & + & + \\
\hline URE & - & - & - & - & - & - & - & - & - \\
\hline H2S & - & - & + & + & - & v & V & - & V \\
\hline CIT & + & + & + & + & + & + & + & + & + \\
\hline ODC & + & + & + & - & - & + & + & - & - \\
\hline ADH & + & + & + & - & - & + & + & - & - \\
\hline ONPG & + & + & + & + & + & + & + & + & + \\
\hline \multicolumn{10}{|l|}{ Other tests } \\
\hline Gram & + & + & + & + & + & + & + & + & + \\
\hline Caseine & + & + & + & + & + & + & + & + & + \\
\hline Lecithine & + & ++ & - & t+t & + & + & + & - & + \\
\hline Starch hydrolysis & + & + & + & + & + & + & + & + & + \\
\hline Catalase & + & + & + & + & + & + & + & + & + \\
\hline Oxidase & + & + & + & + & + & + & + & + & + \\
\hline Mobility & + & + & + & + & + & + & - & + & + \\
\hline RM & + & + & + & + & + & + & + & + & + \\
\hline Anaerobic culture & + & + & - & + & - & - & + & - & + \\
\hline Culture at $45^{\circ} \mathrm{C}$ & + & $\mathrm{v}$ & + & - & $\mathbf{v}$ & + & + & - & + \\
\hline Culture at $55^{\circ} \mathrm{C}$ & - & - & & - & - & - & - & - & - \\
\hline Culture at $65^{\circ} \mathrm{C}$ & - & - & - & - & - & - & - & - & - \\
\hline
\end{tabular}

$(+)$ : Positive result (-): negative result (v): variable

Several bacteria have been identified as having potential for use in biological control. These entomopathogenic bacteria belong particularly to the Bacillaceae family (Starnes et al., 1993). From our study, 9 bacterial strains of the genus Bacillus were isolated from the larvae of $G$. mellonella. After purification, the isolates were identified according to their macroscopic, physiological and biochemical characteristics. Guiraud (2003), Geraldine et al. (1981) and Singleton (2005), confirm their affiliation to the genus Bacillus. According to Brossard and Terry (1984), Bacillus species are ubiquitous microorganisms, the majority grow better at $30^{\circ} \mathrm{C}$ up to $37^{\circ} \mathrm{C}$, many species 
are saprophytes of soil, water, air and plants (Claus and Berkeley, 1986). The strains isolated have all the cultural and microscopic traits of the genus Bacillus described by Euzeby (2007). These catalase positive bacteria with variable response to the oxidase test (Guiraud, 2003) are mobile by cilia, their spores are ellipsoidal to cylindrical (Cloutier and Cloutier, 1992). Isolation of bacteria from nymphs Phyllocnistis citrella revealed the existence of five different bacterial strains. their identification showed that the genus Bacillus is the most frequently encountered. The pathogenicity test with the bacteria isolated showed high mortality of larvae of $P$. citrella (Saiah et al., 2010).

\section{Evaluation of the effect of bacterial isolates on larvae of G. Mellonella}

In order to determine the effect of isolated entomopathogenic bacteria on the larvae of G. mellonella, two bacterial strains (S3 and S4) were chosen. The individuals treated showed remarkable symptoms (figure 2).

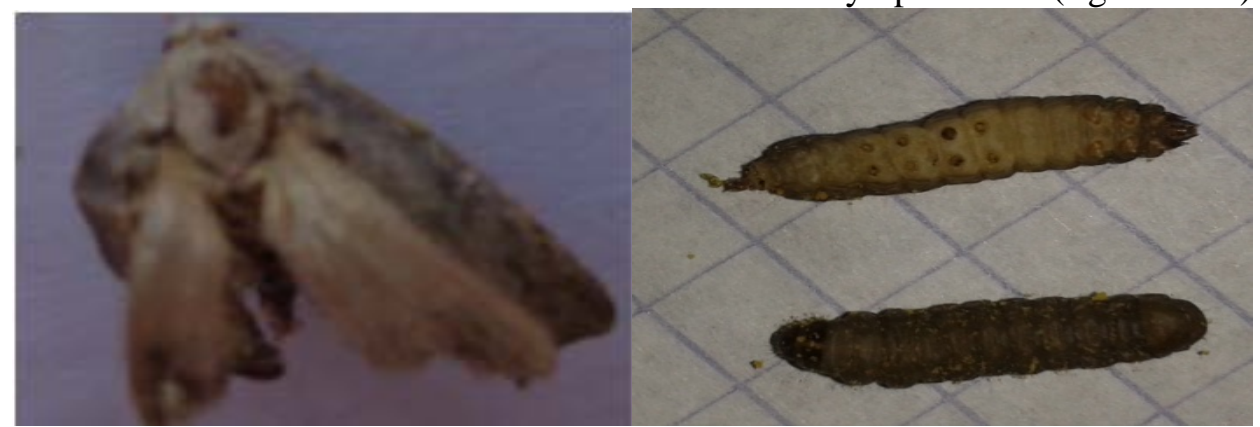

Figure 2. Symptoms observed in individuals treated with bacterial suspensions(A/ appearance deformations in the survivors after the emergence of the butterflies in particular in the wings. B/ blackening and softening of the body just after death due to melanin secretion).

After injection of bacterium Klebsiella pneumoniae into the hemolymph of G. mellonella, the larvae and hemolymph progressively pigmented during infection indicating the production of melanin by the enzyme phenoloxidase (PO). The activity of this enzyme causes deposition of melanin around bacteria by insect hemocytes, to wrap and isolate it (Insua et al., 2013).

Mortality rate: the use of the two strains S3 and S4 against the L5 larvae of G. mellonella gave interesting results. For strain S3, 100\% mortality was observed after 9 days for the high dose, whereas for the mean and the low dose, the effects were different depending on the mode of application of the treatment. They are more pronounced in injection-treated individuals, with $90 \%$ mortality for the mean dose (compared with $66.66 \%$ for ingestion) and $62 \%$ for the low dose (compared to $33.33 \%$ for ingestion) (figure 3).

Injection of S4 strain to G. mellonela caused $83.33 \%, 75 \%$ and $50 \%$ mortality respectively after treatment with D1, D2 and D3 after 3 days. In larvae treated with ingestion, a mortality rate of $66 \%$ was observed after treatment with D1, 41\% for D2 and 25\% for D3, after 9 days. Indeed, Bacillus thurigiensis, like Bacillus popilliae, B. alvei, B. larvae, B. lentimorbus and B. sphaericus, 
possess the particular property of inducing mortality in certain insects (Joung \& Côté, 2001; Lacoursiere \& Boisvert, 2004). These latter justify the harmfulness of the Bacillus by the interaction of their toxins with specific receptors on the epithelial cells of the digestive system, which causes the death of the insect following the disruption of the osmotic regulation of these cells.

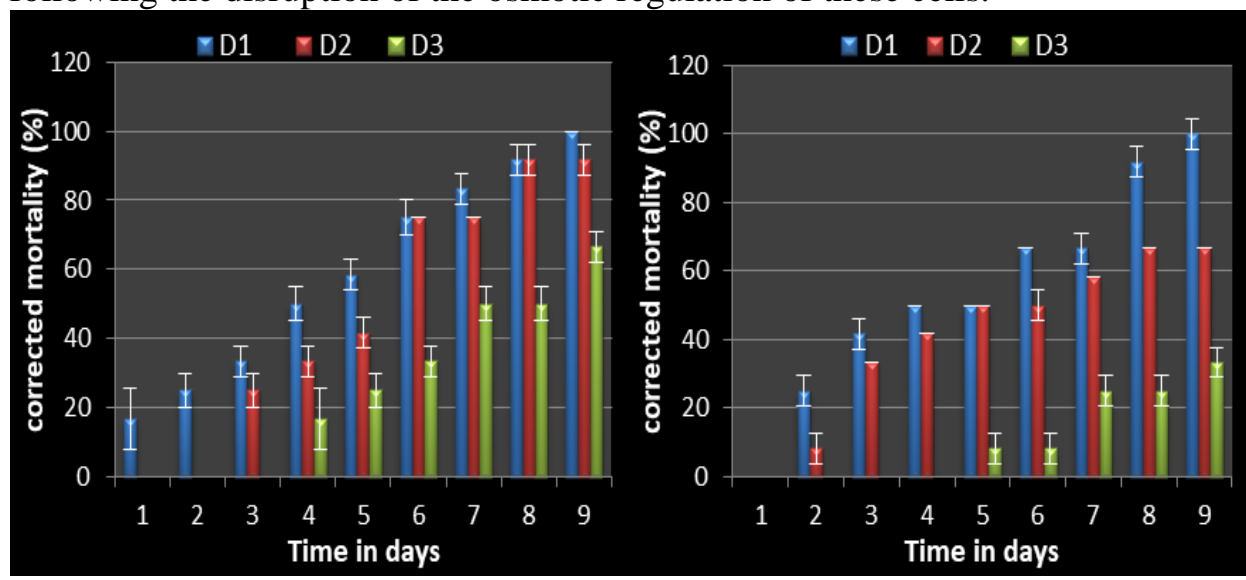

Figure 3: corrected mortality rate in G. mellonella larvae treated with strain S3 (left injection, right ingestion) $\left(\mathrm{D} 1=0.9 * 10^{8}\right.$, D2 $=0.3 * 10^{8}$, D3 = $0.16 * 10^{8}$ ). ANOVA indicate a significant difference in the treated individuels by injection $(F=0,000017)$ and ingestion $(F=0.000000)$ compared to controls. Similarly, the correlation matrix test shows that there is a correlation between the mortality factor and the time factor and also between the mortality factor and the dose factor

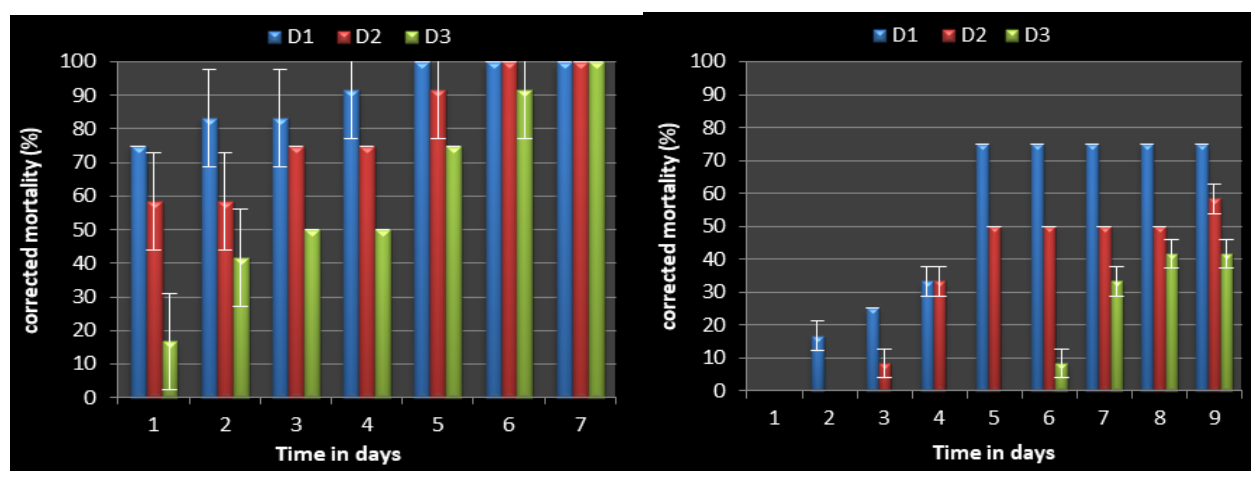

Figure 4: corrected mortality rate in G. mellonella larvae treated by strain S4 by injection (left) and ingestion (right). (D1 $=0.9 * 10^{8}, \mathrm{D} 2=0.3 * 10^{8}, \mathrm{D} 3=$ $0.16 * 10^{8}$ ). (A significant difference was demonstrated by the test of variance analysis in the treated individuels by injection $(\mathrm{F}=0.000487)$ and ingestion $(\mathrm{F}=$ 0.000000) compared to controls. As for the correlation matrix test, it indicates a correlation between the mortality factor and the time factor and also between the mortality and dose factor). 
The present findings are in agreement with El behery et al. (2016) who found that rearing the $G$. mellonella on the different ages of beeswax combs with 4\% Neem Azal-T/S showed that all the tested larvae died during the first week of treatment.

LT50 : lethal times for $50 \%$ of individuals vary depending on the bacteria, the applied doses and the mode of treatment. The larvae of $G$. mellonella treated with S4 have the lowest TL50s, the TL50s increase with the decrease in doses. TL50s are very short for injection mode compared to ingestion.

Table 4. LT50 values recorded in G. mellonella larvae treated with strains S3 and S4

\begin{tabular}{|l|c|c|l|l|l|}
\hline Treatment & \multicolumn{1}{|c|}{ Dose } & \multicolumn{2}{c|}{ Injection } & \multicolumn{2}{c|}{ Ingestion } \\
\hline Strain & & S 3 & S4 & S3 & S4 \\
\hline \multirow{3}{*}{ Doses } & D1 $=0,9 * 108 \mathrm{ufc} / \mathrm{ml}$ & 0,76 day & 0,44 day & 4,14 days & 3,98 days \\
\cline { 2 - 6 } & $\mathrm{D} 2=0,3 * 108 \mathrm{ufc} / \mathrm{ml}$ & 2,01 days & 0,68 day & 4,9 days & 7,58 days \\
\cline { 2 - 6 } & $\mathrm{D} 3=0,16^{*} 108 \mathrm{ufc} / \mathrm{ml}$ & 3,69 days & 1,18 day & 11,69 days & 11,11 days \\
\hline
\end{tabular}

It has been found after treatment of $G$. mellonela with the polyphenols of Bitter Orange (Citrus Aurantium) that this extract showed a valuable efficacy against larvae, an LT50 of 2.34 days was obtained after treatment by dose $20 \mu \mathrm{l} /$ ml (Oulebsir-MohandKaci et al., 2016).

Effects of bacteria on the haemolymphatic composition of $G$. mellonella larvae: the hemolymph assay allowed to plot the regression line which allowed to calculate the concentrations of proteins and carbohydrates haemolymphatic in the controls and treated by the strain S4 .

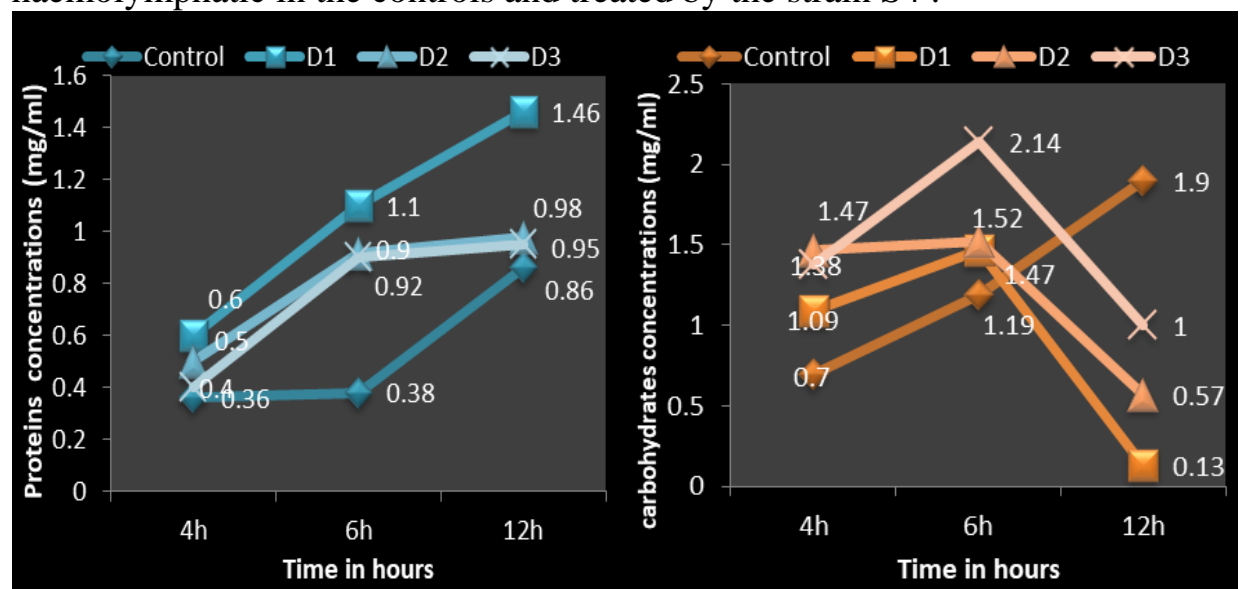

Figure 5: Concentrations (C) of protein and hemolymphatic carbohydrate samples in S4-treated individuals

The injection of the bacterium into the larvae of G. mellonella, resulted in a significant increase in the haemolymph protein content compared to the controls, in particular with the high dose. This increase is proportional to the concentration injected. The carbohydrate content also increased in the treats by 
the 3 doses compared to the controls and this at $4 \mathrm{~h}$ and $6 \mathrm{~h}$. At $12 \mathrm{~h}$, this concentration was markedly decreased in the treated individuals with a normal evolution in the controls (figure 5).

The results obtained by Oulebsir-Mohand Kaci and DoumandjiMitiche(2012) show an important decrease of haemolymph protein concentration compared to controls with an increase in carbohydrate concentration, after treatment of larvae of Locusta migratoria by Pseudomonas fluorescens.

\section{CONCLUSIONS}

The isolation of some bacterial strains belonging to the genus Bacillus from the dead larvae of $G$. mellonella resulted in the identification of 9 species that differed according to their macroscopic, physiological and biochemical characteristics. These isolates were tested on larvae of the same insect in order to confirm their efficacy and to evaluate their toxicity.

The isolates tested against the L5 larvae of the greater wax moth caused very high mortality rates. Comparative examination of the results of the determination of haemolymph protein and carbohydrate showed a difference between the controls and the treated by the bacteria. Finally, it is clear that isolated bacterial strains represent an interesting step forward in the fight against the greater wax moth because they affect its development and metabolism. It is therefore desirable to study further their ecological and toxicological impacts.

\section{REFERENCES}

Akratanakul P. (1987). Honeybee diseases and enemies in Asia: A Practical guide; Food \& Agriculture Organization: Rome, Italy.

Bachelier G. et Gavinelli R. (1966). Dosage globale des glucides du sol par méthodes colorimétrique à l'anthrone et à l'orcinol. Cah.ORSTOM. sér.Pédol., IV(3) :97-103) .

Bradford M. (1976). A rapid and sensitive method for the quantitation of microgram quantities of protein utilizing the principle of protein-dye binding, Analytical biochemistry 72, 248-254.

Brossard et Terry. (1984). Bactériologie systématique. C.R.D.P, Lyon, 220p.

Calderone N. (2000). IPM. Wax moth, mice, wasps and robber bees. Bee Culture Magazine.

Charriere J.-D.\& Imdorf A. (1999). Protection of honey combs from wax moth damage. Am. Bee J. 139, 627-630.

Claus D. et Berkeley R. C. W. (1986). Genus Bacillus Cohn 1872. In Bergey's Manual of Systematic Bacteriology. Edited by P. H. A. Sneath, N. S. Mair, M. E. Sharpe \& J. G. Holt. Baltimore: Williams \& Wilkins. Vol 2: 1105 -1139.

Cloutier C. et Cloutier C., 1992. Les solutions biologiques de lutte pour la répression des insectes et acariens ravageurs des cultures. In Vincent C. et Coderred D., 1992: lutte biologique, pp : 20-21, Ed. Gaïtan Morin, Québec, 671 p.

Elbehery H., Abd El-Wahab T.E. \& Zakri Dimetry N. (2016). Management of the greater wax moth Galleria mellonella with neem azal- t/s, in the laboratory and under semifield conditions. J.APIC.SCI. Vol. 60, n²2. 10.1515/JAS. -2016-0018

Euzeby J.P. (2007). Dictionnaire de Bactériologie Vétérinaire .www.bacdico.net 
Gardan L. et Luisetti G. (1981). Méthodes d'isolement et d'identification des bactéries phytopathogènes. INRA Angers, France. 32p.

Gerard J., Tortora, Berdell R. Funke, Christine L .Case, \& Martin L. (2003). Introduction à la Microbiologie. ERPI, Quebec, 945 p.

Geraldine M., Schofield M. \& School.K.P. (1981). Anumerical taxonomic study of members of the actinomycetaceae and related taxa. J G en Microbiol, 127(2): 237-259.

Guiraud, JP. (2003). Microbiologie alimentaire; Application à l'étude des principaux groupes microbiens. Ed. Dunod, Paris, 651p.

Insua JL., Llobet E., Moranta D., Pérez-Gutiérrez C., Tomás A., Garmendia J., Bengoecheaa JA. (2013). Modeling Klebsiella pneumoniae Pathogenesis by Infection of the Wax Moth Galleria mellonella . Infection and Immunity 10 (81) : 3552-3565.

Joung, J. \& Cote, JC. (2000). Une analyse des incidences environnementales de l'insecticide microbien Bacillus thuringiensis. Ed.AAC. Centre de recherche et développement en horticulture, Bulletin technique n.29, Canada.

Kwadha C.A., Ong’amo GO., Ndegwa PN., Raina SK. and Ayuka T. \& Fombong AT. (2017) The Biology and Control of the GreaterWax Moth, Galleria mellonella. Insects, 8,61.

Larpent JP. (1997). Microbiologie alimentaire, Technique de laboratoire. Ed.Lavoisier, Paris.

Ritter W., Akratanakul P.(2006). Honey Bee Diseases and Pests: A Practical Guide; FAO,V4.

Singleton P.(2005). Bactériologie pour la médecine, biologie et biotechnologie. Dunod, 541p.

Oulebsir-MohandKaci H. et Doumandji-Mitiche B. (2012). Étude de l'impact biologique de Pseudomonas spp. fluorescents sur les métabolites hémolyphatiques et l'histologie du tube digestif des larves L5 du criquet migrateur Locusta migratoria (linné, 1758). Lebanese Science Journal, Vol. 13, No. 2, 99-115.

Oulebsir-Mohandkaci H., Ait Kaki S. \& Behidj-Benyounes N. (2016) Phytochemical Study and Evaluation of Antimicrobial, Antioxidant and Insecticidal Activity of Essential Oils and Polyphenols of Bitter Orange (Citrus Aurantium L.).IJACEBS. 3(1) : 163167.

Paddock F.B. (1918). The Beemoth or Waxworm; Texas Agricultural Experiment Stations: College Station, TX, USA.

Plettner E., Eliash N., Singh N.K., Pinnelli G.R. \& Soroker V. (2017). The chemical ecology of host-parasite interaction as a target of Varroa destructor control agents. Apidologie 2017, 48, 78-92.

Saiah F., Bendahmane BS., Saiah F., Bendahmane BS., Benkada M., Berkani A., Gacemi A. (2010). Isolement et identification de bactéries entomopathogènes à partir de Phyllocnistis citrella Stainton 1856 dans l'Ouest algérien. Entomologie faunistique. 63(3), 121-123

Shimanuki, H. (1980). Diseases and pests of honey bees. In Bee Keeping in the United States; Science and Education Administration, United States Department of Agriculture: Washington, DC, USA; Volume 335, pp. 118-128.

Singleton P., 2005. Bactériologie pour la médecine, la biologie et la biotechnologie. Ed. Dunod, Paris, 541 p.

Starnes R. L., Liu \& Marone P.G. (1993). History, use and future of microbial insecticides. Amer. Entomol, 39 :83-91

Williams J.L. (1987). Insects:Lepidoptera (moths). In Honey Bee Pests, Predators, and Diseases; Morse R., Flottum K., Eds.; AI Root company: Medina, OH, USA; pp. 121141 